\title{
Türk Basın Kanunlarının Genel Görünümü ve 5651 Sayılı Kanunun İnternet Gazeteciliğine Etkileri Üzerine Bir Tartışma
}

\author{
Sinan Baran \\ sinan.brn@hotmail.com
}

Başvuru Tarihi: 20.04.2018

Yayına Kabul Tarihi: 27.06.2018

Yayınlanma Tarihi: 30.07.2018

Öz

İnternetin toplumun temel ihtiyaçlarından biri haline gelmesi sonucunda insanlar enformasyon ihtiyaçlarını karşılamak için internet gazeteciliğini aktif bir şekilde kullanmaya başlamıștır. Bu mecra, haber toplamadan haber yazımına, içeriğin yayınlanmasından hedef kitlesine kadar pek çok farklılığı bünyesinde barındırmaktadır. Bununla birlikte her geçen gün insanların enformasyona en hızlı bir biçimde ulaşma isteklerinden dolayı bu mecranın daha çok tercih edilmesi, internet gazeteciliğinin her yönüyle donanımlı ve sorumlu olmasını gerektirmektedir. Çalışmada 5651 Sayılı "İnternet Ortamında Yapılan Yayınların Düzenlenmesi ve Bu Yayınlar Yoluyla İşlenen Suçlarla Mücadele Edilmesi Hakkında Kanun" un internet gazeteciliği üzerindeki etkilerinin irdelenmesi amaçlanmaktadır. Ayrıca bu mecrada çalışanların yasa çerçevesindeki konumları irdelenmiştir. Buna göre 5651 sayılı yasanın ne internet gazeteciliğine ne de bu mecrada çalışanlara yönelik bir düzenleme içermediği görülmüştür. Bu bağlamda mevcut kaynak ve ilgili yasalardan yararlanılarak literatür yöntemiyle bir kavramsal çerçeve sunulmuştur.

Anahtar Kelimeler: İnternet Gazeteciliği, Basın Kanunu, 5651 Sayılı Kanun, İnternet Gazeteciliği Kanunu. 


\title{
General Outlook of Turkish Press Rules and A Discussion on the Effects of the $\mathbf{5 6 5 1}$ Numbered Law's on the Internet Journalism
}

\author{
Sinan Baran \\ sinan.brn@hotmail.com
}

Date Received: 20.04.2018

Date Accepted: 27.06.2018

Date Published: 30.07.2018

\begin{abstract}
After the internet becomes one of the basic needs of the society, people have actively begun using internet journalism to meet their information needs. This field, contains many different things from the news gathering to the news writing, from the publication of the contents to the target mass. At the same time, because people wants reach to information more fast day by day, this field more preference and internet journalism's be requir responsible and equipped all of aspects. In this study 5651 numbered "Law's about the Arrangement of Publications Made on the Internet and the Struggle Against the Crimes Processed through These Publications" aim to determination of effect on the internet journalism. Additionally, the positions of these workers in the legislative framework have been examined. According to this, it is seen that the 5651 numbered law does not have an arrangement for internet journalism nor for those working in this field. In this context, by using the available resources and related laws a conceptual framework was presented with literature method.
\end{abstract}

Keywords: Internet Journalism, Press Law, 5651 Numbered Law, Internet Journalism Law. 


\section{Giriş}

İnternet gazeteciliği kavramı tüm dünyada internet teknolojisinin gelişmesiyle birlikte yaygınlık kazanmıştır. Dünyanın pek çok ülkesinde paralel bir şekilde gelişim gösteren bu mecra, internet teknolojilerinin gelişmesi ve yaygınlaşması sonucunda her geçen gün daha da çok takip edilir olmuştur. İnternet gazeteciliğinin gittikçe daha çok takip edilmesinin arkasında pek tabii internetin sunmuş olduğu olanakların etkisi önemli rol oynamaktadır. Bunlar arasında internetin hızı, her yerden ulaşılabilir olması, akıllı telefonlardan çeşitli teknolojik araçlara kadar erişimi için uygun alt yapıya sahip olması, birçok yerden ücretsiz kullanılabilmesi ve insanların teknolojiyle git gide daha yakın olmalarına ön ayak olan 21. yüzyılın yaşam pratikleri bu mecranın gücüne güç katmaktadır. Ayrıca bu mecra, geleneksel basının statik yapısından ziyade dinamik içeriğiyle ve okurlarına sunduğu çeşitli imkânlarla da tercih sebebidir. Böylece okurlarına geri bildirim imkânı, etkileşimlilik, hipermetinsellik ve multimedya gibi Web 3.0 teknolojisinin tüm özelliklerini sunarak, geleneksel basından kendisini kalın çizgilerle ayırmaktadır.

Dolayısıyla internet gazeteciliğinin ne denli önemli olduğu aşikardır. İnternet gazeteciliğinin hiçbir yasal çerçeve içerinde güvenceye alınmaması, internet gazeteciliğinin gelişimi önündeki en büyük engellerden birini oluşturmaktadır. Aynı şekilde diğer bir engel ise internet gazeteciliğinde çalışanların Basın İş Kanunu kapsamına dahil edilmemeleridir. Pratikte incelendiğinde geleneksel basın çalışanlarıyla dijital ortamlarda haber üretenler düşünce veya fikirsel olarak aynı işi yapmalarına rağmen dijitalde çalışanların söz konusu Kanun kapsamında tutulmamaları meslek çalışanlarını zora sokmaktadır. İnternet ile ilgili ilk genel yasa 2007 yılında 5651 Sayılı Kanun kapsamında çıkmıştır. Bu kapsamda çalışmada söz konusu 5651 Sayılı Kanun'un, internet gazeteciliğine ve çalışanlarına yönelik kapsamı incelenmiș ve söz konusu kanunun internet gazeteciliğine ve çalışanlarına yönelik etkilerinin belirlenmesi amaçlanmıştır. 5651 sayılı yasanın sadece internet gazeteciliği bağlamında değerlendirilmesi çalışmanın sınırlılığını oluşturmaktadır. Ayrıca bu minvalde bir çalışmanın yapılmaması çalışmanın önemini oluşturmaktadır. Çalışmada bilimsel gözlemi merkeze alan, literatür taramasına yönelik bir yöntem uygulanmıştır.

\section{Osmanlıdan Günümüze Genel Olarak Türk Basın ve Yayın Kanunu Tarihi}

İlk Türk basın kanunu muadillerine göre epey geç çıkmıştır. Bunun nedeni ülkemize matbaanın geç gelmesi, buna bağlı olarak da ilk gazetelerin geç çıkmasıdır. Osmanlı Devleti'nde çıan ilk Türkçe gazete Vakayi-i Mısriye'dir (1828). Daha sonra ise Vakayi-i Giridiye (1830) çıkmıştır. Mısır valisi Kavalalı Mehmet Ali Paşa, bu iki Türkçe gazeteyle basının propaganda gücünden yararlanarak, Osmanlı devletine karşı basını farklı dillerde etkin bir biçimde kullanmıştır. Buna karşılık Padişah II. Mahmut'un direktifi doğrultusunda günümüz Türkiye sınırları içerisinde çıkan ilk gazete ile (Takvim-i Vekayi- 1831) Osmanlı Devleti basının gücünden istifade etmek istemiştir. Osmanlı Devleti sınırları içerisinde çıkan gazetelere yönelik ilk aşamada bir basın kanunu yoktur. Fakat İspanya Engizisyonundan kaçan Yahudilerin beraberinde getirdikleri matbaaya yönelik Osmanlı Devleti, Türkçe ve Arapça kitap basımına izin vermemiştir1.

Osmanlıda ilk matbaa kurulduktan yaklaşık iki buçuk asır sonra, Padişah III. Ahmed, 5 Temmuz 1727'de bir "Hattı-ı Şerif” ile imparatorluk matbaasının (Matbaa-i Amire) 
kuruluşunu ilan etmiştir. Bu arada iki kısıtlayıcı koşul getirilir: Dini içeriği olan yazılar, diğer bir deyişle, Kuran ve açıklaması ile, yani "tefsir" ile ilgili; Peygamber Hz. Muhammed'in sözleri ile, yani "hadisler" ile ilgili eserler ve dini kurallar, yani "fikıh" ile ilgili eserler kesinlikle matbaaca basılmayacaktır (Babinger, 2004, 12-13). Bu her ne kadar doğrudan basına yönelik bir karar olmasa da bu fermanın alandaki ilk düzenleme olduğu söylenebilir. Osmanlı kendi matbaasını kurduğunda da basım alanında sınırlamalar devam etmiştir.

Matbaa, padişah vakfına cüz başına bir akçe resim ödemek zorunda olduğundan mühürsüz yani resmi ödenmemiş kitap satamazdı. Başka biri basım evi açarak ona rekabet de edemezdi. Basılacak kitap sayısını, fiyatını da matbaacı değil, hükümet tayin ederdi. Matbaa açma hakkı izin belgesiyle, tek ya da ortak "malikâne", yani daha sonraki terimle "imtiyaz" olarak verilirdi. Çok muhtemel olarak matbaaya tayin edilen ulemanın bir vazifesi de bu işlere bakmaktı. Basımcılık II. Mahmut dönemine kadar devletçe verilen bir tekel olarak kalmıştır. Ve ancak gazeteciliğin başlamasından sonra özel bir girişim işi olabilmiştir (Berkes, 2016, 58).

Devlet sınırları içerisinde çıkan ilk birkaç gazeteden sonra basına yönelik yasal düzenlemenin gerekliliği anlaşılmış olunacak ki bu alanda da ilk düzenlemeler getirilmiştir. Basına ilişkin ilk yasak 1858 tarihli Ceza Kanunu'nun 138. Maddesinde yer almaktadır. Bu madde saltanat ve yöneticiler aleyhine zararlı yayın yapılmasını yasaklamaktadır. Aynı kanunun 139. Maddesi ise genel ahlaka aykırı yazıların ve müstehcen resimlerin yayınlanmasını yasaklamaktadır. Basına yönelik ilk düzenleme ise 1864 tarihli Matbuat Nizamnamesidir. Ceza Kanunu gibi Fransa'dan esinlenilerek kaleme alınan Nizamname gazete çıkarmayı hükümet iznine bağlamaktadır. Genel ahlaka aykırı yazıların, padişah aleyhinde yazıların yanında devlet memurları ve yabancı diplomatların aleyhine yazılar yayınlanması da yasaklanmıştır (Cankaya ve Yamaner, 2012, 99). Nizamnamenin ikinci bölümü cezalara ayrılmıștır. Bu bölümde şu gibi suç ve cezalar yer almaktadır: Ruhsatsız gazete çıkarmak; gazetenin imzalı bir sayısını ilgili devlet dairesine göndermemek; hükümetten gelen resmi yazıları yayınlamamak; Devlet-i Âliyye'nin iç güvenliğini bozacak suçlardan birinin icrası için bazı kişileri kışkırtmak, genel adaba ve milli ahlaka aykırı yazılar; Hazreti padişahiye saldırı sayılabilecek yazılar; bakanlara dokunacak söz yazılması; dost hükümdarlara dokunacak deyimler kullanılması; meclisleri, mahkemeleri ve devletçe kurulan heyetleri kötüleyecek yazılar; devlet memurlarının aleyhinde kötü yazı yazılması, yabancı diplomatların kötülenmesi; halkın aşağılanması (Topuz, 2012, 45). Üç yıl sonra, 27 Mart 1867 tarihinde Tasvir-i Efkar ve Muhbir gazetelerinin hükümetin Girit politikasını eleştirmeleri üzerine (Aktaran: Alver, 2011, 279) çıkartılan bir kararnameyle (Kararname-i Ali), Matbuat Nizamnamesi kapsamı dıșında kalan durumlarda da hükümete gazete kapatma yetkisi tanınmıştır. Bundan amaç, hükümet aleyhindeki yayınları önlemektir. Kararnamede özetle;

İstanbul'da yayımlanan gazetelerin; bir süredir kullandıkları dilin ve tuttukları yolun, ülkenin genel yararına aykırı aşırılıklarının, devlete bile dil uzatmalarının, ayrıca fesat aleti olarak birtakım zararlı fikirleri ve yalan haberleri yazanların, hükümetçe tasvip edilmediği" belirtilerek, "Asayişin ve ülkenin muhtaç olduğu düzenin korunması, bu kaideye aykırı davranan gazetelerin bütün devlete ve millete olan zararlarının önlenmesi için, matbuat nizamnamesi hükümleri dışında olarak, hükümetçe eğitici ve önleyici tedbirler alınmasına karar verilmiştir, denilmiştir. 
1864 tarihli Matbuat Nizamnamesi'nde gazete sansürü yer almadığı halde, 1867 tarihli Ali Kararname ile basın özgürlügü ortadan kaldırılarak, gazeteler kapatılmaya (Muhbir, Ayinei Vatan, Utarit gazeteleri kapatılmışlardır), gazeteciler de sürgüne gönderilmeye başlanmıştır. Geçici olarak çıkarıldığı bildirilen bu kararname hükümlerine, Abdülaziz'den sonra tahta geçen İkinci Abdülhamit tarafından da sık sık başvurulmuştur (Girgin, 2001, 59). Gazetelerin kapatılması ve gazetecilerin sürgün edilmesine neden olan Kararname-i Ali'nin basını susturmak için yeterli gelmemesi üzerine, 11 Mayıs 1876 tarihinde yeni bir kararname yayınlanarak basına sansür uygulaması hayata geçirilmiştir. Sadrazam Mahmut Nedim Paşa tarafından yayınlanan Ali Kararname'de kısaca şöyle denilir; "Osmanlı basınında çıkan yazılara hükümet gerekli dikkati göstermiş ve çoğu zaman gazeteleri süreli veya süresiz olarak kapatmışsa da basın inzibat altına alınamamıştır. Bunun için gazetelerin baskıdan önce denetimine karar verilmiştir (MEGEP, 2008, 15). Böylece gazetelere ilk sansür uygulaması, Mahmut Nedim Paşa yönetiminde yapılmış ancak uzun sürmemiștir (Alver, 2011, 281).

Hüseyin Avni Paşa Süleyman Paşa Harp Okulu talebeleriyle birlikte sarayı kuşatarak Abdülaziz'i tahtan indirmişler ve V. Murad'ı tahta çıkarmışlardır. Ancak çok geçmeden V. Murad'ın yerine II. Abdülhamit 1876'da padişah olmuştur (Çı̆̆, 2007, 73). II. Abdülhamit'in tahta çlkmasından sonra ilan edilen Kanun-i Esasi'nin 12. Maddesine "Basın kanun dairesinde serbesttir" hükmü getirilmiştir. Ama basına tanınan bu özgürlük kısa sürmüştür (Çakır, 2007, 34). Aynı anayasanın 113. maddesi sultana gerekli gördüğünde sıkıyönetim ilan etme ve devlet güvenliği bakımından zararlı görebileceği kimseleri yurt dışına sürgün etme yetkisini de vermektedir (Mazıcl, 1996, 135). Mithat Paşa'nın sadrazamlı̆̆ sırasında bir basın kanunu tasarısının hazırlanması için bir komisyon kurulmuştur. Komisyon kısa zamanda bu tasarıyı hazırlayarak 1877 Nisan'ında Mebusan Meclisi'ne getirdi. Tasarının birinci bölümünde basımevlerinin kuruluşu ve işletilmesiyle ilgili hükümler yer alıyordu. İkinci bölüm, gazetelere ve süreli yayınlara ayrılmıştı. Üçüncü bölümde de basın yoluyla işlenecek suçlar ve bunlara verilecek cezalar sıralanmıştır (Topuz, 2012, 51). Mithat Paşa'nın sadrazamlıktan alınmasından hemen sonra 19 Mart 1877 'de yayımlanan bir irade ile, basın hükümetin çalışmalarına yönelttiği eleştiriler konusunda uyarıldı. Meclis'in dağıtıldığı 1878'den sonra da çeşitli sansür kurulları kuruldu, basına sansür uygulanmaya başlandı. 1880'de uygulama daha da genişletilerek siyasal olmayan gazete ve dergiler de sansür kapsamına alındı. 1888 ve 1894 Matbaa Nizamnameleriyle önce basım evleri sonra da kitapçılar denetim altına alındı (Çakır, 2007, 34-35).

İstibdat döneminin en önemli olaylarından biri de gazetecilerin ilk kez grev yapmalarıdır. 1901 yılında, İkinci Abdülhamit'in tahta çıkışının 25. yıldönümü kutlanmış; bu vesileyle o güne kadar gazetelere yapıştırılan iki paralık pul vergisi, basını hoşnut etmek amacıyla kaldırılmıştır. Pul vergisi kaldırılınca, her gazete ortalama 80-90 liralık bir gelir artışı sağlamıș ve gazete patronlarının geliri belirli ölçüde artmıştır. Bu nedenle gazetelerde çalışanlar da bu gelir artışından pay istemişlerdir. 1898, 1900 ve 1901 tarihlerinde çlkarılan iradelerdeki hükümlerle, gazetelerin kapatılması, yazarların cezalandırılmaları, gazete imtiyazlarının kaldırılması gibi, devlet güçleri tarafından fikir müesseselerine yönelik eylemler sonucu, basın özgürlügü tamamen yok edilmiștir. Bu tür uygulamalar 1907 yılına kadar yoğunlaşarak sürmüş ve Osmanlı'da İkinci Meșrutiyet dönemine kadar, basında zorunlu bir suskunluk yaratılmaya çalışılmıştır (Girgin, 2001, 58-70). 
II. Meşrutiyet 23 Temmuz 1908'de (10 Temmuz 1324) ilan edildi. Meşrutiyet'in ilanı ile birlikte basında sansür yasağı kalktı ve bir yayın patlaması yaşandı. Osmanlı Devleti'nde yaşayan farklı dilden ve dinden her ulus, kendi fikirlerini dile getirdiği gazeteler ve dergiler çıkardı. Basın, Meşrutiyet döneminde toplumun sesi haline geldi (Dağlar, 2008, 141). II. Meşrutiyetin kısa süreli özgürlük ortamı (Demir, 2015, 367) getirmesine karşılık, bu süreç gazetecilikle hiç ilgisi olmayan kişilerin de gazete çlkarmalarına zemin hazırlamıștır. Büyük bir çoğunluğunun gazetecilik üzerine deneyim sahibi olmadığı bu kişilerin sadece kişisel düşüncelerini ifade etmek için gelişigüzel yayın yapmaya kalkmaları, basın alanında tam bir kargaşaya yol açmıştır. Bu durumun etkisiyle basın hayatına tam bir anarşi ortamı hâkim olmuştur (Aktaran: Seyhan, 2013, 496). Matbuat hürdü ama bir müddet sonra Galata Köprüsü üzerinde gazeteciler İttihatçıların fedaileri tarafından vurulmaya başlandı (Ortaylı, 2011 , 18). Dört gazeteci öldürülmüş, katiller yakalanamamıș ve ağır bir baskı havası yaratılmıştır (Topuz, 2012, 87). Sansüre son verse de eleştiriye tahammül edemeyen yeni hükümet, yeni adımlar atan ve hızla serpilen Osmanlı basınının olgunlaşmasına izin vermeyerek, eleştiriler ekseninde olumlu yönde dönüşüm şansını yitirmiştir (Torun, 2015, 116). 1909 yasasının yürürlüğe girmesinden sonra yaklaşık sekiz ay süren basın özgürlüğü, tekrar ortadan kaldırılmıştır. Öyle ki, 1909'da 353 olan gazete sayısı 1912'de 45’e düşmüştür (Mazıcı, 1996, 137).

31 Mart 1909 olayının ardından İstanbul işgal edildi. Abdülhamit tahttan indirildi ve sıkıyönetim ilan edildi (Çakır, 2007, 171). 31 Mart olayından çok kısa bir süre sonra, 28 Nisan 1909'da Mebusan Meclisi'ne basın özgürlügünü kısıtlayıcı yeni bir basın kanunu tasarısı getirdi ve bu, gazeteciler arasında çok geniş tepkiler yarattı. Tasarı her yandan saldırıya uğradı. Ancak Meclis uzun tartışmalara yol açan bu tasarıyı, 14 Temmuz 1909'da kabul etti. 14 Temmuz 1909 tarihli Matbuat Kanunu, 8 Ağustos 1931'e kadar, 22 yıl yürürlükte kalmışsa da 15 kez değişikliğe uğramıştır. Yapılan değişiklerin başlıcaları şunlardır (Topuz, 2012, 84-86);

- Yazı işleri müdürleri için yükseköğretim veya yedi yıllık idadi (lise) diploması zorunluluğu; Siyasi gazete imtiyazı almak için İstanbul'da 500, taşrada 200 lira depozite yatırılmasi; askerlerin yazı yazmasının yasaklanması (3 Mart 1912 tarihli geçici kanun).

- Edep ve ahlak kurallarına aykırı yazı ve resimlerin yasaklanıp toplatılması (16 Şubat 1913 tarihli geçici kanun).

- Mebusların ve Ayan üyelerinin sorumlu gazete müdürü olmalarının yasaklanması; gazete satıcılarının polisten belge almaları zorunluluğu (9 Mart 1913 Tarihli geçici kanun).

- Devletin iç ve dış güvenliğini bozabilecek biçimde yayın yapan gazetelerin bakanlar kurulu kararıyla kapatılabilmesi (9 Kasım1913 tarihli geçici kanun).

- Askeri sansür memurlarının izni olmadan ordu hareketleriyle ilgili haberlerin yazılmaması (25 Ağustos 1914 tarihli geçici kanun).

- Sıkıyönetim bölgelerinde sansür kurulunun izni olmadan gazeteyayınlanmaması (5 Şubat 1919 tarihli kararname).

- İç güvenlik ve dış ilişkilerle ilgili belge yayınlanmaması (5 Ağustos 1920 tarihli kararname).

II. Meşrutiyet'in ilanı üzerine, toplumsal ve siyasal alanda yaşanan karmaşa, aynen basında da görülmektedir. Bu dönemde gazeteler, siyasal gelişmelerin önde gelen belirleyicileri arasında yer almışlardır. Millî Mücadele sırasında ise, Atatürk'ün önce 
Sivas'ta İrade-i Milliye ve arkasından Ankara'da Hâkimiyet-i Milliye gazetelerini çıkarmış olması, basının siyasal gelişmeler içindeki yerinin ve öneminin başlıca kanıtı olarakgösterilebilir. Millî Mücadele sırasında ve hemen sonrasında işbirlikçi, mandacı, hilafetçi ve saltanatçı yayın yapan İstanbul basınındaki gazetecileri yargılamak üzere, millî güçlere karşı yürüttükleri kampanya nedeniyle, TBMM İstanbul'a bir İstiklal Mahkemesi göndermişse de bu mahkeme tüm gazeteci sanıkların beraatlarına 2 Ocak 1924'te karar vermistir. Bununla birlikte Şeyh Sait isyanı üzerine 4 Mart 1925'te çıkarılan Takrir-i Sükûn Kanunu, hükümete basın özgürlügünü kısıtlama ve gazete kapatma yetkisini tanımıștır. Bu yasanın varlığına karşın, 1930'da Serbest Cumhuriyet Firkasının kurulması, basında yeni bir canlanmaya ve yeni muhalif gazetelerin çıkmasına neden olmuştur. Ancak yine de, bu dönem uzun sürmemiştir. Serbest Cumhuriyet Fırkasının kendini feshetmesinden sonra hükümet basın üzerindeki denetimini yeniden kurmak yoluna gitmiştir (Yetkin, 2010, 2).

Basın gerek günlük çalışmalarında, gerekse yeni yayınlar için izin alabilmek bakımından çok sıkı kontrol altındaydı. Basını denetleyebilmek için 1938'de bir Basın Birliği de kuruldu (Karpat, 2010, s. 161). 25 Temmuz 1931 günü kabul edilen Basın Kanunu yetmiş maddeden oluşuyordu. Kanunun getirdiği en önemli kısıtlama 50. Maddedeydi. Bu madde şöyle diyordu (Odyakmaz, 2003, 125);

\begin{abstract}
Madde 50 - Memleketin umumî siyasetine dokunacak neşriyattan dolayı İcra Vekilleri Heyeti karart ile gazete veya mecmualar muvakkaten tatil olunabilir. Bu suretle kapatılan gazete veya mecmuanın neşrine devam edenler hakkında 18 inci madde hükmü tatbik olunur. Bu suretle kapatılan bir gazetenin mesulleri tatil müddetince başka bir isim ile gazete çıkaramaz
\end{abstract}

20 Kasım 1940'ta İstanbul ve daha yedi ilde ilan edilen sıkıyönetim de basın üzerinde ciddî bir denetim ve yönlendirmede bulunmuștur. Gazete ve dergi kapatma yetkisini geniş bir biçimde kullanmıştır. İstanbul'un basının merkezi olduğu ve yine sıkıyönetim kapsamı içinde bulunan Ankara'nın da basın dünyasında ikinci önemli kent olduğu düşünülürse, sıkıyönetimin basın üzerinde çok büyük bir denetim kurduğu söylenmelidir (Yetkin, 2010, 5). 26 Ağustos 1946 tarihinde Başbakan Recep Peker tarafından meclise sunulan ve 9 Eylül 1946 tarihinde Adalet Komisyonu, 11 Eylül 1946 tarihinde de İçişleri Komisyonu'nda görüşülerek meclis genel kuruluna gelen Matbuat Kanunu'nun bazı maddelerinin değiştirilmesi hakkındaki kanun teklifi, 13 Eylül 1946 tarihinde 14. Birleşimde görüşülmeye başlanmıştır (Şentürk, 2015, 209). 21 Temmuz 1946 seçimleri öncesinde, TBMM'nin yedinci dönemi 14 Haziran 1946 tarihinde tatile girmeden önce önemli demokratik adımlar atılmıștır. Bunlardan biri de basın özgürlüğü konusundadır. 13 Haziran 1946 tarihinde 1931 tarihli Matbuat Kanunu'nun hükümete gazete kapatma yetkisi veren 50. Maddesi kaldırılmıştır (Odyakmaz, 2003, 125).

1946 yılında ilk çok partili seçimler yapılmıştır. 1946 seçimlerinde çok partili hayata girilmiș ama çift dereceli seçim ve açlk oy-kapalı tasnif sistemi geçerli olmuștur (Ortayl, 2011, 93). Muhalefetin, ülkenin her yerinde örgütlenemediği için bütün seçim çevrelerinde aday gösteremediği bir sırada yapılan 1946 seçimini CHP büyük bir çoğunlukla kazandı (Dursun, 2008, 379). 1950 yılında yapılan seçimlerde açık oy-kapalı tasnif sistemi uygulanmamıștır. Böylece, 14 Mayıs'ta Türkiye sandık bașına gitmiș, yaklașık 8.5 milyon seçmenin \%88'i oy kullanmıștır. 408 Demokrat, 69 Halk Partili, 1 Millet Partili ve 9 bağımsızdan oluşan bir meclis ortaya çıkmıştır (Lewis, 2015, 417-418). 
14 Mayıs 1950 seçimleriyle CHP yerini DP’ye bırakmış, seçim sonuçlarıyla oluşan ortamda basın da yeni yasasına kavuşmuştu. Yeni hükümet, kuruluşundan çok kısa bir süre sonra 21 Temmuz'da Cumhuriyet döneminin ilk basın yasası olan 1931 Matbuat Kanunu'nu ve değișikliklerini yürürlükten kaldırmıștı. Yeni Basın Kanunu'nun bu kadar hızlı çıkmasının nedeni elbette, CHP'nin daha önce bu yönde yaptığı çalışmalardan yararlanılmasıdır. Yasa, 15 Temmuz 1950'de Meclis'te kabul edilerek 21 Temmuz'da yürürlüğe girmiştir (Yıldız, 1996, 487). İkisi geçici olmak üzere toplam 46 maddeden meydana gelen 5680 Sayılı Basın Kanunu, 1931 Matbuat Kanunu'nun hükümete tanıdığı geniş yetkileri kaldırmıştır. Artık gazete çıkarmak için izin almak gerekmiyor; bildirimde bulunmak yeterli görülüyordu. Basın suçları Toplu Basın Mahkemeleri'nde yargılanacak ve bu, basın için bir güvence niteliği taşıyacaktı. Gazete sahipleri, yayımlanan haber ve yazılardan dolayı ceza sorumluluğu taşımayacaklardı (Kösedă̆, 2016, 2029).

5681 Sayılı Matbaalar Kanun'u da bu dönemde çıkmış ve yürürlükte olan kanun şöyledir3;

Madde 1 - Matbaa kurulması izne bağlı değildir. Ancak matbaa açılmadan evvel kurulacağı yerin en büyük mülkiye amirine bir beyanname verilir.

Madde 2 - Beyanname muhteviyatında her hangi bir suretle vukua gelecek değişiklikler, bu değişikliklere taallük eden vesikalarla birlikte beş gün içinde birinci maddede yazıll mercie bildirilir.

Madde 3 - Bu kanun hükmüne göre beyanname vererek matbaa açanlara (tabi) denir.

Madde 4 - Tabiler, bastıkları eserlerden ikişer nüshasını basmanın sona erdiği günün çalışma saati içinde, bulundukları yerin Cumhuriyet Savcısı ile en büyük mülkiye amirine vermeye mecburdurlar.

Madde 5 - Basın Kanunu gereğince mevkutenin çıkarılması için lüzumlu beyannamenin verildiği anlaşılmadıkça mevkutelerin matbaalarda basılması yasaktır. Bunlar ilgili 08.02.2008 tarihinde yürürlüğe giren 5728 sayılı kanunla iki değişiklik yapılmıştır. Söz konusu değişiklikler ise şöyledir;

Madde 6 - (Değişik: 5728/132 md.) Bu Kanunun 1 inci maddesine göre beyanname vermeden matbaa açanlarla 2, 4 ve 5 inci maddeleri hükümlerine aykır hareket edenler, Cumhuriyet savcısı tarafindan yüz Türk Lirasından beş bin Türk Lirasına kadar idarî para cezasiyla cezalandirllır.

Madde 7 - (Değişik: 5728/133 md.) Hakikate aykırı beyanname veren kimse, üç aydan iki yıla kadar hapis cezasiyla cezalandırılır.

Yüz yıla yakın süredir sosyal güvencelerden yoksun olarak çalıșan gazeteciler 13 Haziran 1952'de çıkarılan "Basın Mesleğinde Çalışanlarla Çalıştıranlar Arasındaki Münasebetleri Düzenleyen 5953 Sayılı Kanunla” ilk kez sosyal güvenlik sistemi kapsamına alınmıştır. $\mathrm{Bu}$ Kanunla gazetecilerin elde ettiği haklar şunlardır (MEGEP, 2008, 53).

- Sendika kurabilmek,

- Sosyal sigortalardan yararlanmak,

- Isşverenin gazeteciyle yazılı iş anlaşması yapması zorunluluğu,

- İş anlaşmasını bozmak isteyen gazete sahiplerinin gazeteciye kıdemine göre tazminat ödemesi,

- Haftalık tatil, yıllık ücretli izin 
Kabul edildiği șekliyle oldukça özgürlükçü olan 5680 Sayılı Basın Kanunu 21 Temmuz 1950 'de yürürlüğe girmiştir. Ne yazık ki basın açısından son derece sevindirici olan bu durum pek de uzun sürmemiștir (Cankaya ve Yamaner, 2012, 100). Bu 1954 yıllarının ilk aylarında Demokrat Parti hükümetinin Meclis'e getirdiği "Neşir Yoluyla Veya Radyo İle İşlenecek Cürümler Hakkında Kanun Tasarısı” 9 Mart 1954'te kabul edilerek sekiz gün sonra yürürlüğe girmiștir. Bu kanunla "namus, şeref veya haysiyete tecavüz edilmesi veya hakarette bulunulması veya itibar kıracak veya şöhret veya servete zarar verebilecek bir hususun isnad edilmesini” önlemek amaçlanmıștır. Kanunla ayrıca suç sayılabilecek bir yazı çıktığı zaman savcıların doğrudan doğruya kovuşturma açmalarının yolu açılmıştır. Bu dönemde ispat hakkı da yoktur. 6-7 Eylül olayları akabinde de basına çeşitli yasaklar getirilmiştir. DP Hükümeti, 1956'da basın özgürlüğünü kısıtlayan iki yasa daha çıkarmıştır. Bu yasaların birincisiyle "Yayın Yoluyla Ve Radyoyla İşlenen Suçlar Kanunu"na yeni maddeler eklenmiş, ikincisiyle de Basın Kanunu'nda bazı değişiklikler yapılmıștır. 1958 yılının ilk günü yayınlanan bir kararnameyle de "ilan ve reklamların tek elden dağıtımı" kabul edilmiștir. 27 Nisan 1960'da Tahkikat Komisyonu kurularak yasağa uymayan gazete ve dergilerin basımı ve dağımı önleneceği ve yayın yasaklarına ısrarlı șekilde uymayan yayınların kapatılacağı hükmü getirilmiştir (Topuz, 2012, 195-208).

27 Mayıs 1960 yılında ordu, darbe yaparak Demokrat Parti hükümetinin görevini sonlandırmıștır. 27 Mayıs İhtilali Türk basınının büyük bir bölümü tarafından olumlu bir şekilde, hatta coşkuyla karşılanmıştır (Öymen, 2014, 303). Neşir yoluyla veya radyoyla işlenecek cürümler hakkındaki 6334 ve 6732 Sayılı Kanun'lar 12 Ekim 1960'ta 94 Sayılı Kanun'la iptal edilmiștir. 1 Aralık 1960'ta Ceza Kanunu'nun 481'inci maddesinde yapılan bir değişiklikle de ispat hakkı tanınmıștır (Topuz, 2012, s. 228). Basına yönelik kapsamlı düzenleme ise, 1961 Anayasası ile yapılmış; basının özgür olduğu ve sansür edilemeyeceği; basın alanında faaliyet göstermek için ön izin almak ve mali teminat göstermek koşulu aranmayacağı; gazete ve dergi kapatma, toplatma, yayın yasağı koyma gibi işlemlerin ancak Anayasa'nın temel ilkeleri çerçevesinde çlkarılan kanunlarla düzenlenebileceği öngörülmüştür (Alver, 2011, 279). 5953 Sayılı Kanun 1954 yılında 6253 Sayılı Kanunla ve 1961 yılında 212 Sayılı Kanun'la değişikliğe uğramıștır. Sonuncu değişiklik basın işverenleri çevresinin çeşitli tepkilerine yol açmıştır (Oğuzman, 1966, 859). Tepkilere yol açan çalışan gazetecilerin haklarını güvence altına alan "Basın Mesleğinde Çalışanlarla Çalıștıranlar Arasındaki Münasebetleri Düzenleyen 5953 Sayılı Kanun” 04.01.1961 yılında 212 Sayılı Kanun'la şu düzenlemeleri getirmiştir.

- Akdin işveren tarafindan feshi ve kıdem tazminatı

- Mülkiye amirine bildirilecek hususlar

- Tecrübe müddeti

- Akdin tatbik edilmediği hallerde fesih

- Ücret

- Mukavele dişı yazılar

- Askerlikte ve gebelikte ücret:

- Mahkümiyet veya yayının tatili halinde ücret:

- Ölüm tazminatı:

- Haftalık izin

- Yillık ücretli izin

- Çalışma Müddeti ve fazla mesai 
13.6.1952 tarihinde kabul edilen 5953 Saylı bu Kanun 1954, 1961, 1963, 1964, $1965,1971,1973,2002,2003$ ve 2008 ylllarında güncellenmiștir. Son güncellemeyle de $26,27,29,30$ ve 14 ve 27 . maddeleri değiştirilmiştir. ${ }^{4}$

1960 askeri darbesi ertesinde 7.1.1961 tarihinde yürürlüğe giren 195 Sayılı Kanun’la Basın İlan Kurumu oluşturuldu. "Resmi ilanlar ve yabancı menșeli reklamlar bu kurum kanalıyla yayınlanabilir" denilerek bütün ilan ve reklamlar serbest bırakıldı (Sönmez, 2010, 63). 195 Sayılı Basın İlan Kurumu Teşkiline Dair Kanun, 19.2.1979, 22.6.1984, 5.2.1988, 5.8.1988, 10.7.2009 ve 1.1.2011 tarihlerinde günümüze kadar 6 sefer güncellenmiştir. ${ }^{5}$

7 Mart 1962'de yayınlanmış olan 38 Sayılı Tedbirler Kanunu ise "27 Mayıs Devrimi”ni söz, yazı, haber, havadis, resim, karikatür ve başka araçlarla yersiz, haksız veya gayrimeşru göstermeye çalışanları" suçlamaya yönelik çıkmıştır (Topuz, 2012, 236). Radyo yayınları 1964 yılına kadar Basın-Yayın ve Turizm Genel Müdürlüğü yönetiminde kalmış, bu tarihte çıarılan 359 Sayılı TRT Yasası ile TRT Kurumuna devredilmiştir. 359 Sayılı Yasanın çıkışı 1961 Anayasa sının 121. Maddesine dayanmaktadır. Sözü geçen madde de Türkiye'deki radyo ve televizyon yayınlarının tarafsız, özerk bir kamu kuruluşuna devredilmesi ve bunun için bir yasa çıkarılması öngörülmekte idi. 1963 yllında yasanın yapılmasına başlanmış, 1963 Aralık ayında yasalaşmıştır. Yürürlüğe girişi ise 1 Mayıs 1964'dür. Böylece, Türkiye yayıncıllk tarihinde ilk kez, var olan radyo yayınları ile, ileride kurulacak olan televizyon yayınları yasal güvence altına alınmış oluyordu. TRT Kurumunun kurulmasını öngören Yasa, daha sonra yayınlardan ötürü Kurum ile Hükümetler arasındaki sürtüşmeler nedeni ile yeniden gözden geçirilmiş ve kimi maddeleri 1972 yılı Şubat ayında çıkarılan 1568 Sayılı Yasa ile değiștirilip, tarafsız bir kuruluş durumuna getirilmiştir. Yapılan en önemli değişiklik, kurumun bundan böyle özerk bir iktisadi kamu kuruluşu olmayıp, tarafsız bir kuruluş durumuna getirilmesidir (Aziz, 1976, 118-119).

12 Eylül, basının yoğun baskılar altında olduğu bir dönemdir. 1980-1984 yılları arasında çok sayıda basın davası açılmış, gazeteciler tutuklanmış, pek çok gazete kapatılmıştır. 12 Eylül İhtilali'nin beraberinde getirdiği merkeziyetçi ve baskıcı yapı ile amaçlanan, toplumu apolitikleştirerek, şiddet ve terör olaylarını bastırmak ve devletin gücünü artırmayı sağlamaktır. 12 Eylül yönetimi, bütün bu amaçlarını gerçekleştirmek için, basını, kişisel hak ve özgürlükleri kısıtlayıcı denetimler getirmiş; dernekler, sendikalar, odalar, üniversiteler merkezi otoritenin tam denetimi altına alınmıştır (Erdem, 2007, 111-122). 29 Eylül'de ise, Basın Kanunu'nda değişiklik yapan bir yasa önerisi Danışma Meclisi'nde, yalnızca bir dakika süren oylama ile kabul edilir. Anti-demokratik hususlar içeren ve basını zora koşacağı bilinen bu yasalarla halkın haber alma özgürlüğü önemli ölçüde kısıtlanmaktadır. Bu yasa gereğince birkaç gün sonra gazetelerin halktan para toplayarak eşya vermesi yasaklanır. Resmi Gazete 'de yayımlanan tebliğe göre, gazetelerin doğrudan doğruya veya pazarlama firmaları aracılı̆̆ ile buzdolabı, televizyon, firın, video, otomobil vs. vermesi men edilir. Aksini yapacakların cezalandırılacağı belirtilir (Duman, 2014, 173-174). 11.11.1983 tarihinde 2954 Sayılı "Türkiye Radyo Ve Televizyon Kanunu" çıkartılmıştır. Bu Kanunla radyo ve televizyon ile tüm medya araçlarından yapılan yayınların düzenlenmesine ve özerkliği ve tarafsızlı̆̆ Anayasada hükme bağlanan Türkiye Radyo-Televizyon Kurumunun kuruluş, görev, yetki ve sorumluluklarına ilişkin esas ve usullerini 
belirlemek amaçlanmıştır. 2954 Sayılı bu Kanun kurulduğu yıldan itibaren 16 kez güncellenmiştir. ${ }^{6}$

1986 yılına gelindiğinde ise 1927'den kalma 1117 Sayılı “Küçükleri Muzır Neşriyattan Koruma Kanunu" güncellenerek, 18 yaşından küçüklerin maneviyatı üzerinde muzır tesir yapacağı anlașılan mevkute ve mevkute tanımına girmeyen diğer basılmış eserleri düzenleyen 3266 Sayılı Kanun çıkartılmıştır. Söz konusu Kanun 12.3.1986, 26.5.1988, 21.7.2004 ve 19.2.2014 tarihinde 4 defa değiștirilmiştir. ${ }^{7}$

13.4.1994 tarihinde radyo ve televizyon yayınlarının düzenlenmesine ve Radyo ve Televizyon Üst Kurulunun kuruluş, görev, yetki ve sorumluluklarına ilişkin esas ve usulleri belirlenmesine yönelik 3984 Sayılı 42 maddeden oluşan RTÜK Kanunu çıkartılmıștır. 15.02.2011 yılında 3984 Sayılı RTÜK Kanunu güncellenerek 6112 Sayılı Kanun ile değiştirilmiştir. 6112 Sayılı RTÜK Kanunu 12.07.2012, 03.05.2013, 11.09.2014, 07.09.2016, 06.01.2017, 09.02.2017, 29.4.2017, 08.03.2018, 8.3.2018 ve 08.03.2018 tarihlerinde güncellenmiştir. ${ }^{8}$

Demokrat Parti iktidarının 15 Temmuz 1950'de, TBMM'de kabul edilerek 21 Temmuz 1950 tarihinde yürürlüğe koyduğu 5680 Sayılı Basın Kanunu günümüze kadar birçok değişikliğe uğramıştır (Yıldırım, 2009, 292). 15.07.1950 tarihinde kabul edilen 5680 Sayılı ilk basın Kanunumuz 09.06.2004 tarihinde 5187 Sayılı yasayla değiștirilmiștir. 2004 yılında kabul edilen 5187 Sayılı Basın Kanunu'nun 9. Maddesi Anayasa Mahkemesinin 2008 yılında aldığı karar ile güncellenmiștir. Buna göre "Süreli yayın sahibinin beyanname verdiği tarihten itibaren bir sene içinde süreli yayın yayımlanmaz veya yayımlandıktan sonra yayıma üç yıl müddetle ara verilirse beyanname hükümsüz kalır ve sağladığı hak ortadan kalkar. 556 Sayılı Markaların Korunması Hakkında Kanun Hükmünde Kararname hükümleri saklıdır. Ancak, bu Kanunun yürürlük tarihinde 5680 Sayılı Basın Kanunu gereği mevkute neşredenler, 556 Sayılı Markaların Korunması Hakkında Kanun Hükmünde Kararname hükümleri gereği mevkute neşretmekten alıkonulamazlar" şeklinde olan Kanun maddesi, "Süreli yayın sahibinin beyanname verdiği tarihten itibaren bir sene içinde süreli yayın yayımlanmaz veya yayımlandıktan sonra yayıma üç yıl müddetle ara verilirse beyanname hükümsüz kalır ve sağladığı hak ortadan kalkar. 556 Sayılı Markaların Korunması Hakkında Kanun Hükmünde Kararname hükümleri saklıdır" şeklinde değiștirilmiştir. ${ }^{9}$

\section{İnternet Gazeteciliğinin Yasal Problemleri}

İnternet gazeteciliğinin gelişim gösterdiği yıllarda ve günümüzde internet gazeteciliğine yönelik ve internet gazeteciliğinde çalışanlara yönelik bir yasal düzenleme çıkmamıştır. İnternet gazetelerinin her geçen gün daha fazla okur tarafından takip edilmesi ve enformasyon ihtiyacının ciddi bir biçimde bu mecradan sağlanmasına rağmen bu mecrayla ilgili yasal düzenlemelerin olmaması bu alanda ciddi bir eksikliğe işaret etmektedir. Yasa içerisinde internet gazeteciliğinin her yönüyle düzenlenmesi hem okurlar hem de içerik üreten internet gazeteciliğinde çalışanlar için oldukça önemlidir. Okurlar için önemlidir çünkü internetin sınırsız evreninde sınırsız enformasyon tüm dünyanın hizmetine bir tıkla sunulmaktadır. Ne olduğu ve kime hizmet ettiği belli olmayan profesyonel gazetecilik anlayıșından uzak gazetecilik meslek ilkelerini ihlal eden birçok haber sitesi bir virüs gibi enformasyon yayabilmektedir. Bundan dolayı internet gazeteciliği yapmak için kurumsallaşmanın yolu açılmalıdır ve yasal çerçeveyle de bu mecraya yeşil 
ışık yakılmalıdır. İnternetin son derece hızlı olmasından dolayı enformasyon denetiminde problemler çıkmaktadır. Yasal olarak belli başlı kurallar konulmak suretiyle internet gazetelerinin okurlarına karşı sorumluluk bilinci oluşacaktır. İnternet gazetelerine yönelik çıkacak yasa bu mecranın özgürlüğünü kısıtlamayıp okurların doğru haber erişimi için önemli bir adım olacaktır.

İnternet gazetelerinde çalışanların 5953 Sayılı "Basın Mesleğinde Çalışanlarla Çalıştıranlar Arasındaki Münasebetlerin Tanzimi Hakkında Kanun" kapsamına alınması, bu mecranın olgunlaşmasında ve pratikte de profesyonelleşmesinde önemli katkıları olacaktır. Bunların gerçekleşmesi için internet haber sitelerinin Basım İlan Kurumu'ndan resmi ilan alıp geleneksel gazeteciliğe tanınan hak ve hukuktan yararlanmaları elzemdir.

2008 yılında 6 milyon civarında olan genişbant internet abonesi, 2017 yılı üçüncü çeyrek sonu itibarıyla 67,9 milyonu aşmıştır (btk.gov.tr). Bu verinin bir neticesi olarak internetten haber okuma oranları da artmıştır. 5 Ekim 2017 Alexa verilerine göre haber sitelerinin aylık toplam ziyaret edilme sayısı Hürriyet gazetesinde: 173. 43 Milyon, Milliyet gazetesinde: 130. 86 Milyon, Sözcü gazetesinde: 106. 35 Milyon, Sabah gazetesinde: 59.80 Milyon, Haber 7'de: 51.76 Milyondur (wpmavi.com). 19 25 Mart 2018 haftalık klasik gazete satışları ise şöyledir;

Tablo 1: Klasik gazetelerin haftalık tirajlarını gösteren tablo (gazetetirajlari.com).

\begin{tabular}{|l|c|c|}
\hline Gazete & Satış & Önceki Hafta \\
\hline Hürriyet Gazetesi & 312 Bin 037 & 317 Bin 468 \\
\hline Sabah Gazetesi & 306 Bin 163 & 306 Bin 321 \\
\hline Sözcü Gazetesi & 262 Bin 069 & 258 Bin 056 \\
\hline Posta Gazetesi & 234 Bin 748 & 240 Bin 233 \\
\hline Habertürk Gazetesi & 203 Bin 241 & 205 Bin 021 \\
\hline Türkiye Gazetesi & 135 Bin 172 & 134 Bin 727 \\
\hline Milliyet Gazetesi & 130 Bin 023 & 130 Bin 470 \\
\hline
\end{tabular}

İnternet haber sitelerinin ve klasik gazetelerin takip edilme oranları incelediğinde aralarında çok büyük bir farkın olduğu hemen dikkat çekmektedir. Bu denli farka rağmen internet gazetelerine yönelik internet gazeteleri yayın kanununun ve internet gazetelerinde çalışanlara yönelik bir kanunun olmaması medya alanında önemli bir açıktır. Burada şuna dikkat çekmekte yarar vardır. Yukarıdaki veriler incelendiğinde çıkan internet haber sitelerinin birçoğu geleneksel gazeteye de sahiptirler. Zaten bunların çoğu internete haberleri aktararak internet haberciliğine başlamışlardır. Bunların haricinde değerlendirilmeye alınmamış onlarca geleneksel gazetesi bulunmayan haber siteleri bulunmaktadır. Basın İlan Kurumu'nun resmi ilanları haber sitelerine de vermesiyle medya alanında tekelleşmenin önüne geçilmesi ve demokratik bir toplumun temini ve tesisi için önemli bir adım olacaktır.

Haber, enformasyon ve düşünceleri iletmehakkı ile haber, enformasyonve düşünceleri alma hakkı olarak belirtilen bu iki temel hak, iletişim araçlarında çalışanların, hiç kimsenin müdahalesi olmadan ve tam bir güven içinde haber, enformasyon ve düşünce toplama ve iletmedeki rollerin nesnel bir şekilde uygulama hakkına geniş ölçüde bağlıdır (Şahin ve Avşar, 2016, 134). Bu bağlamda internet haberciliğinde çalışanların da yasayla statülerinin ve haklarının belirlenmesi gerekmektedir. İnternet gazeteciliğiyle ilgili hiçbir yasal düzenlemeye bugüne kadar gidilmemiștir. Bu sorun internet gazeteciliği alanına özel bir mevzuatla çözümlenmeye çalışılırken, 
basın kartlarının dağıtımını yapan Basın Yayın Enformasyon Genel Müdürlüğü'nün mevzuatında da değişiklik yapılması gerekmektedir. İnternet yayıncılığı alanında çalışan gazeteciler aynı zamanda Basın Kanunu ve Basın Kartı Yönetmeliği gibi düzenlemelerin dışında kaldıklarından, Basın Kartı sahibi olamamakta ve özellikle TBMM, Başbakanlık gibi devlet kurumlarının bilgi paylaşımında akreditasyon sorunları yaşamaktadırlar (Sözeri ve Güney, 2011, 26-76).

Internet gazeteciliğinden ziyade genel mahiyette internet ile ilgili ilk yasal düzenleme 04.05.2007 tarihinde 5651 Sayılı "İnternet Ortamında Yapılan Yayınların Düzenlenmesi Ve Bu Yayınlar Yoluyla İşlenen Suçlarla Mücadele Edilmesi Hakkında Kanun "la yapılmıştır. Bu kanunla içerik sağlayıcı, yer sağlayıcı, erişim sağlayıcı ve toplu kullanım sağlayıcıların yükümlülük ve sorumlulukları ile internet ortamında işlenen belirli suçlarla içerik, yer ve erişim sağlayıcıları üzerinden mücadeleye ilișkin esas ve usullerinin düzenlenmesi amaçlanmıştır. 5651 Sayılı söz konusu kanun 2008, 2011, 2013, 2014, 2015 ve 2016 tarihlerinde güncellenmiștir. 5651 Sayılı "İnternet Ortamında Yapılan Yayınların Düzenlenmesi Ve Bu Yayınlar Yoluyla İşlenen Suçlarla Mücadele Edilmesi Hakkında Kanun" en son şekliyle aşağıdaki konularda düzenlemeye gitmiştir.

İçerik, yer ve erişim sağlayıcıları, yönetmelikle belirlenen esas ve usûller çerçevesinde tanıtıcı bilgilerini kendilerine ait internet ortamında kullanıcıların ulaşabileceği şekilde ve güncel olarak bulundurmakla yükümlü kılınmıștır. Bu yükümlülügü yerine getirmeyen içerik, yer veya erişim sağlayıcısına Başkan (Bilgi Teknolojileri ve İletişim Kurumu Başkanı) tarafından iki bin Türk lirasından elli bin Türk lirasına kadar idarî para cezası verileceği kararlaştırılmıştır. İçerik sağlayıcı, internet ortamında kullanıma sunduğu her türlü içerikten sorumlu tutulmuştur. Aynı zamanda içerik sağlayıcı, bağlantı sağladığı başkasına ait içerikten dolayı sorumlu tutulmamıştır. Ancak, sunuş biçiminden, bağlantı sağladığı içeriği benimsediği ve kullanıcının söz konusu içeriğe ulaşmasını amaçladığı açıkça belli ise genel hükümlere göre sorumlu tutulmuştur. Benzer şekilde internet ortamında yapılan ve içeriği aşağıdaki suçları oluşturduğu hususunda yeterli şüphe sebebi bulunan yayınlarla ilgili olarak erişimin engellenmesine karar verileceği belirtilmiștir. Bu unsurlar ise șöyledir;

- Intihara yönlendirme

- Cocukların cinsel istismarı

- Uyuşturucu veya uyarıcı madde kullanılmasını kolaylaştırma

- Sağlık için tehlikeli madde temini

- Müstehcenlik

- Fuhuş

- Kumar oynanması için yer ve imkân sağlama

- Atatürk Aleyhine İşlenen Suçlar Hakkında Kanunda yer alan suçlar

Erişimin engellenmesi kararı, soruşturma evresinde hâkim, kovuşturma evresinde ise mahkeme tarafından verileceği ifade edilmiştir. Sorușturma evresinde, gecikmesinde sakınca bulunan hallerde Cumhuriyet savcısı tarafından da erișimin engellenmesine karar verileceği belirtilmiştir. Ayrıca yaşam hakkı ile kişilerin can ve mal güvenliğinin korunması, millî güvenlik ve kamu düzeninin korunması, suç işlenmesinin önlenmesi veya genel sağlı̆ın korunması sebeplerinden bir veya bir kaçına bağlı olarak hâkim veya gecikmesinde sakınca bulunan hâllerde, Başbakanlık veya millî güvenlik ve kamu düzeninin korunması, suç işlenmesinin önlenmesi veya 
genel sağlığın korunması ile ilgili bakanlıkların talebi üzerine Başkan tarafından internet ortamında yer alan yayınla ilgili olarak içeriğin çıkarılması ve/veya erişimin engellenmesi kararının verilebileceği ifade edilmiștir ${ }^{10}$.

5651 Sayılı Kanun ile ilk defa (btk.gov.tr);

- Internet aktörlerinin (içerik sağlayıcı, yer ve erişim sağlayıcı, toplu kullanım sağlayıcı) tanımı yapılmıș ve bu aktörlerin hak ve sorumlulukları belirlenmiştir.

- Yasada suçlar bakımından erişimin engellenmesi usul ve esasları düzenlenmiștir.

- Internet ortamında yayınlanan içerik nedeniyle haklarının ihlal edildiğini iddia eden kişilere iliş̧kin; içeriğin yayından çıkarılmasını sağlama ve cevap hakkı uygulamalarına ilişkin usul ve esaslara yer verilmiștir.

- Konusu suç teşkil eden (ve/veya küçükler için zararlı olan) içerik kapsamında filtreleme usulü öngörülmüştür.

- Türkiye'de internet ortamındaki yayınlardan kanunda belirtilen katalog suçlara ilişsin şikâyetlerin yapılabileceği internet bilgi ihbar merkezi (ihbarweb.org.tr) kurulmuştur.

5651 Sayılı Kanun incelendiğinde ne internet gazeteciliğiyle ne de internet gazetelerinde çalışanlarla ilgili doğrudan bir hüküm getirmemektedir. Söz konusu yasa internet gazeteciliğinin yapısıyla değil doğrudan internette faaliyet gösterenlerle ilgili çıkmıştır.

5953 Sayılı Kanun'un kapsamı şöyle tarif edilmiştir; “Bu Kanun hükümleri Türkiye'de yayınlanan gazete ve mevkutelerle haber ve fotoğraf ajanslarında her türlü fikir ve sanat işlerinde çalıșan ve İş Kanunundaki "işçi" tarifi şümulü haricinde kalan kimselerle bunların işverenleri hakkında uygulanır." Bu tanıdan yola çıkacak olunursa internet haberciliğinde çalışanların da pek tabii bu yasa kapsamına girmeleri gerekmektedir. 02.01.1961 tarihinde çıkan 195 Sayılı Basın İlân Kurumu Teşkiline Dair Kanun'da ise bu kurumun görevleri şöyle sıralanmıştır;

1. Resmî ilânların mevkûtelerde yayınlanmasında aracı olmak,

2. Kurumun idaresine iștirak eden mevkûtelere, basın dernek ve sendikalarına en çok beş yıl vâde ile kredi açmak,

3. Yönetmelikte tespit edilecek, basında fikren veya bedenen çalışanlar gibi basın mensuplarına, vâdesi iki yılı geçmemek üzere borç para vermek,

4. Basının her türlü ihtiyaçlarını temin etmek (makine, kâğıt, mürekkep gibi),

5. Yönetmelikte tespit edilecek basın mensupları ile bunlardan çalışamaz durumda olanlardan yardıma muhtaç bulunanlara ve ölenlerin ailelerine yardım etmek,

6. Yukarıdaki bendde yazılı olanlar için diğer her türlü sosyal teșebbüslerde bulunmak,

7. Bu kanunla kendisine verilen diğer görevleri ifa etmek.

5953 Sayılı Kanun gibi 195 Sayılı Kanun'da da basın mesleğinde çalışanlarla ilgili bölümler yer almaktadır. Lakin internet gazeteciliğinde çalışanlar bu kanundan da yararlanamamaktadır. Bu mecrada çalışanlara yönelik yasal bir dayanak olmadığından sendikal hakları da yoktur.

\section{Sonuç}

Türk basın tarihi her ne kadar batılı muadillerine göre ortaya geç çıksa da, pek çok tecrübeyi yaşayarak günümüze gelmiştir. Bu tecrübelerin ardında ülkede meydana gelen siyasi ve askeri olayların rolü oldukça büyüktür. Bu unsurlar, Türkbasın tarihinde yasal süreçlerin başlatılmasında ve daha sonraki mevcut yasaların değiştirilmesinde 
kırılma noktası olmuştur. Bu kırılmalara göre basın konumlandırılmış ve bu suretle basın alanında düzenlemelere gidilmiştir. Osmanlı döneminde ilk kez 1858 yılında basını ilgilendiren karar alınmıș daha sonra 1964 'te Matbuat Nizamnamesi çıkartılmıștır. Bunlar Türk basın yasa tarihinin ilklerini oluşturmaktadır. Bu süreçten sonra I. Meşrutiyet'te II. Meşrutiyette, 31 Mart Vakası'nda, Kurtuluş Savaşı sırasında, Cumhuriyetin ilk yıllarında ve çok partili siyasi hayata geçiş yıllarında olmak üzere basın alanında kanunlar çıkarılmış, var olan kanunlar değiştirilmiş ve dönemin konjonktürüne göre basın șekillendirilmiștir. Çok partili siyasi hayata geçilene kadar ki yapılan tüm basın düzenlemeleri genel olarak gazete çıkarma koşullarını ve gazete yoluyla ișlenecek suçların kapsamını belirlemeye yönelik olmuștur. Gazeteci haklarına yönelik ilk yasal düzenleme ise çok partili siyasi hayat sonrasında 1952 yılında çıkmıştır.

Günümüzde de internet gazeteciliğine ve bu mecrada çalışanlara yönelik herhangi bir kanunun çıkmaması Türk basın yasası tarihimizde yaşanılan gecikmenin bir başka halkasını oluşturmaktadır. Dünyada ve Türkiye'de hemen hemen aynı yıllarda çıkan ve yaygınlaşmaya bașlayan internet gazeteciliğinin tıklanma oranlarına bakıldığında en çok tercih edilen haber mecraları olarak kendisini göstermektedir. Buna rağmen ve onlarca haber sitesinin varlığına, yüzlerce de bu mecrada çalışanların olmasına rağmen her hangi bir yasal düzenlemeyle veya yasa değișikliğiyle bu mecrada çalışanların 5953 Sayılı "Basın Mesleğinde Çalışanlarla Çalıștıranlar Arasındaki Münasebetlerin Tanzimi Hakkında Kanun "un kapsamı dışında tutulması basın alanında çalışanlar arasındaki eşitsizliklerin olduğunu göstermektedir. İnternet ile ilgili ilk olarak 2007 yılındayapılan 5651 Sayılı "İnternet Ortamında Yapılan Yayınların Düzenlenmesi Ve Bu Yayınlar Yoluyla İşlenen Suçlarla Mücadele Edilmesi Hakkında Kanun "un da özel olarak ne internet gazeteciliğiyle ne de bu mecrada çalışanların yasal hak ve statüleriyle ilgili yasal düzenleme getirmediği görülmektedir. $\mathrm{Bu}$ alandaki yasal boşluk hem internet gazeteciliği için hem de internet gazeteciliğinde çalışanlar için devam etmektedir.

Oysa basın günümüzde tüm yönleriyle kültürün hem bir parçası hem de bir şartı olmuştur. Çağımızda da demokrasinin olmazsa olmazlarından birisi konumundadır. $\mathrm{Bu}$ suretle gerek basının yapısı gerekse de basın alanında çalışanların koşulları hem kültürün hem de demokrasinin yapı taşlarını oluşturmaktadır. Fakat özellikle basın mesleğinde çalışanların aynı işleri yapmalarına rağmen yasal çerçevede bir birlerinden ayrı tutulmaları çeşitli problemlere yol açmaktadır. Demokrasinin bir gereği olan eşitlik ilkesine aykırı olan bu durum yapılacak bir yasal düzenlemeyle hakkaniyetine kavuşturulmalıdır. Daha iyi şartlarda ve daha iyi teknik araç gereçler sayesinde basın ișçileri daha nitelikli haberler ortaya koyacaklardır. Bununla birlikte büyük medya kuruluşlarının yanı sıra, dijital ortamda internet gazeteciliği yapan kişilerin çoğalması çok sesliliğe imkân tanıyacak aynı zamanda da yerel bölgelerin haberleri de daha nitelikli bir biçimde tüm dünyaya servis edilebilecektir.

İlerde yapılacak araştırmalarda internet ortamında gazetecilik yapanların konuyla ilgili istek ve görüşlerinin yer aldığı bir çalışmanın yapılması faydalı olacaktır. Ayrıca internet ortamında yapılan haberlerin okunma oranları ve geleneksel medya okunma oranları arasında bir kıyaslama yapılması suretiyle, internet gazeteciliği yapanların ve bu mecrada çalışanların yasal bir ortamdan eksik olmalarının doğuracağı muhtemel sorunlara dikkat çekilmesinin alana önemli katkıları olacaktır. 


\section{Notlar}

${ }^{1}$ Ayhan Ceylan, "Tanzimat Dönemi Osmanlı Basım ve Yayımında Hukuki Düzen (1839-1876)", Türk Hukuk Tarihi Araştırmaları, Sayı: 2006 (Bahar), s. 139-155.

${ }^{2} 25$ Temmuz 1931 Tarihli Matbuat Yasasının tamamı için bk. http://www.resmigazete.gov.tr/arsiv/1867.pdf

${ }^{3} 5681$ Sayllı “Matbaalar Kanunu”nun güncel tam metni için bk. http://www.mevzuat.gov.tr /MevzuatMetin/ 1.3.5681. pdf, Erişim Tarihi: 26.03.2018

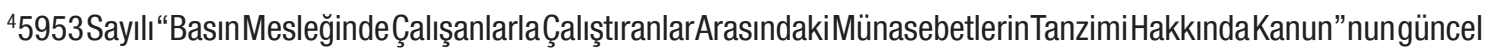
metni için bk. http://www.mevzuat.gov.tr/Metin.Aspx?MevzuatKod=1.3.5953\&Mevzuatlliski=0\&sourceXmISearch, Erişim Tarihi: 26.03.2018

${ }^{5} 195$ Sayılı "Basın Illan Kurumu Teşkiline Dair Kanun "un güncel metni için bk. http://www.mevzuat.gov.tr/Metin. Aspx?MevzuatKod=1.4.195\&Mevzuatlliski=0\&sourceXmISearch, Erişim Tarihi: 26.03.2018.

${ }^{6} 2954$ Sayılı "Türkiye Radyo Ve Televizyon Kanunu”nun son hali için bk. http://www.mevzuat.gov.tr/Metin. Aspx?MevzuatKod=1 5.2954\&Mevzuatlliski=0\&sourceXmISearch, Erişim Tarihi: 26.03.2018

${ }^{7} 1117$ Sayılı “Kü̧̈ükleri Muzır Neşriyattan Koruma Kanunu'nun tam metni için bk. http://www.mevzuat.gov.tr/Metin. Aspx?MevzuatKod=1.3.1117\&Mevzuatlliski=0\&sourceXmISearch, Erişim Tarihi: 26.03.2018

${ }^{8} 6112$ Sayılı "Radyo Ve Televizyonların Kuruluş Ve Yayın Hizmetleri Hakkında Kanun "un güncel hali için bk.http:// www.mevzuat.gov.tr/Metin.Aspx?MevzuatKod=1.5.6112\&Mevzuatlliski=0\&sourceXmISearch=RADY0\%20VE\%20 TELEV\%C4\%BOZYONLARIN, Erişim Tarihi: 26.03.2018

${ }^{9} 5187$ Basın Kanunu'nun tüm maddeleri için bk. http://byegm.gov.tr/turkce/mevzuat Erişim Tarihi: 26.03.2018

${ }^{10} 5651$ Sayılı Kanun'un tam metni için bk. http://www.mevzuat.gov.tr/MevzuatMetin/1.5.5651.pdf, Erişim Tarihi: 28.03.2018.

\section{Kaynakça}

Alver, F. (2011). Gazetecilik Bilimi ve Kuramları. İstanbul: Kalkedon Yayınları.

Aziz, A. (1976). Radyo ve Televizyona Giriş. Ankara Üniversitesi Siyasal Bilgiler Fakültesi Yayınları.

Babinger, F. (2004). Müteferrika ve Osmanlı Matbaası: 18. Yüzyılda İstanbul'da Kitabiyat (Çev: Nedret Kuran - Burçoğlu ve Machiel Kiel). İstanbul: Tarih Vakfı Yurt Yayınları.

Berkes, N. (2016). Türkiye'de Çağdaşlaşma (23. Bs.). İstanbul: Yapı Kredi Yayınları.

BTK. (2017). Pazar Verileri Raporu 2017 Yılı 3. Çeyrek. Erişim Tarihi: 27.03.2018. https://www.btk.gov.tr/ File $/$ ? path $=$ R00T $\% 2$ f $1 \% 2$ fDocuments $\% 2$ fSayfalar $\% 2$ f Pazar Verileri\%2f2017-Q3.pdf

Cankaya, Ö. ve Yamaner, M. B. (2012). Kitle İletişim Özgürlüğü (2. Bs.). İstanbul: Beta Yayınları.

Çakır, H. (2007). Gazeteciliğe Giriş. Konya: Tablet Yayınları.

Çı̆̆, Ü. (2007). 19. Yüzyılda Osmanlı'da Gazetecilik Hareketleri: Takvim-i Vekayi'den Vilayet ve Özel Girişim Gazetelerine, (Ed. Suat Gezgin). Türkiye'de Yerel Basın. İstanbul: İstanbul Üniversitesi İletişim Fakültesi Yayınları.

Dağlar, O. (2008). II. Meşrutiyet'in İlanının İstanbul Basını'ndaki Yansımaları (1908). İstanbul Üniversitesi Siyasal Bilgiler Fakültesi Dergisi, (38). 141- 159.

Demir, Ş. (2015). İktidar-Basın İlişkilerinin Osmanlı Devleti'nde Görünümü (18311918). The Journal of Academic Social Science Studies, (33), 367-377. 
Duman, H, H. (2014). Türk Basın Tarihi. Eskişehir: T.C. Anadolu Üniversitesi Yayını.

Dursun, D. (2008). Siyaset Bilimi (4. Bs.).İstanbul: Beta Basım Yayım.

Erdem, B. N. (2007). 12 Eylül İhtilali'nin Yerel Basının Haber Seçimleri Üzerindeki Etkisi: Hakimiyet Gazetesi Örneği, (Ed. Suat Gezgin). Türkiye'de Yerel Basın. İstanbul: İstanbul Üniversitesi İletişim Fakültesi Yayınları.

Girgin, A. (2001). Türk Basın Tarihi'nde Yerel Gazetecilik. İstanbul: İnkılâp Kitabevi.

Karpat, K. (2010). Türk Demokrasi Tarihi. İstanbul: Timaş Yayınları.

Kösedağ, M. S. (2016). Türk Basın Kanunu'nda Yapılan Değişikliklerin Yazılı Basında Temsili. Uluslararası Sosyal Araştırmalar Dergisi, 9(43). 2023-2051.

Lewis, B. (2015). Modern Türkiye’nin Doğuşu (Çev: Boğaç Babür Turna) (8. Bs.). Ankara: Arkadaş Yayınevi.

Mazıcı, N. (1996). 1930’a Kadar Basının Durumu ve 1931 Matbuat Kanunu. Atatürk Yolu AÜTI TED, cV, 131-154.

MEB, MEGEP. (2008). Türk Basınının Doğuşu ve Gelişimi. Ankara.

Odyakmaz, N. (2003). Cumhuriyet Döneminde Anayasal Düzenlemeler ve Basın Özgürlüğü. İstanbul Üniversitesi İletişim Fakültesi Dergisi| Istanbul University Faculty Of Communication Journal, (17). 121-144.

Oğuzman, M. K. (1966). Gazetecilerin Mesleki ve Sosyal Hakları ve Bunların Korunması. İstanbul Üniversitesi Hukuk Fakültesi Mecmuası, 32(2-4), 858883.

Oran, B. (2017). Türkiye'de En Çok Ziyaret Edilen Siteler: TOP 100 | En Çok Tıklanan Siteler. Erişim Tarihi: 27.03. 2018. https://wpmavi.com/blog/en-coktiklanan-siteler.html\#2

Ortaylı, İ. (2011). Türkiye'nin Yakın Tarihi (8. Bs.) İstanbul: Timaş Yayınları.

Öymen, O. (2014). Bir Propaganda Silahı Olarak Basın. İstanbul: Remzi Kitabevi.

Seyhan, S. (2013). II. Meşrutiyet Dönemi Mizah Basını ve İçeriklerinden Seçilmiş Örnekler. Electronic Turkish Studies, 8(3). 494-516.

Sönmez, M. (2010). Medya, Kültür, Para ve İstanbul İktidarı. İstanbul: Yordam Kitap.

Şahin, M. ve Avşar, Z. Basın İș Kanunu, Sorunlar ve Güncelleme Tartışmaları. Sosyal Güvenlik Dergisi, 6, (2),113-138.

Şentürk, A. (2016). 1931 Matbuat Kanunu'ndaki değişiklikler üzerine kronolojik bir değerlendirme: Basın hürriyeti bağlamında meclis tartışmaları ve basındaki yankılar. Tarih Incelemeleri Dergisi, 30(1), 199-230.

Tamer, T, A. (2015). “ Matbuat Hürriyetimiz Var Mı Yok Mu?” 1908 Sonrası Basın Özgürlüğü ve Matbuat Kanunu Tartışmaları. Kebikec: İnsan Bilimleri İçin Kaynak Araştırmalı Dergisi, (40). 93-118.

Topuz, H. (2012). II. Mahmut'tan Holdinglere Türk Basın Tarihi (4. Bs.). İstanbul: Remzi Kitabevi.

Yetkin, B. (2010). 1945-1950 Arası" Demokratikleşme" Sürecinde Basın. Yakın Dönem Türkiye Araştırmaları, (17-18).1-38. 
Ylldırım, T. (2016). Türk Gazetecilik Tarihi Üzerine Bir Deneme-I. Yeni Türk Edebiyatı Araştırmaları, 285-324.

Yıldız, N. (1996). Demokrat Parti İktidarı (1950-1960) ve Basın. Ankara Üniversitesi Sbf Dergisi, 51(01). 481-505. 